31 Som gammel kristelig sædvane anføres i En liden Haandbog som indeholder allehonde nyttige Offuelser vdi Gudelighed, 1578, en række "klokkebønner" i Hans Christensen Sthens Skrifter, II, 2003, s. 314-315 og 319 linje 58-69, jf. bind I, 1994, s. 28-30. Udbredt var også "En kort bøn at bede hver time, når klokken slår" i Rasmus Hansen Reravius' En liden Bønebog, 1575.

32 til melodien "Hjælp Gud, at jeg nu kunne", der anvendes syv gange af Ernst.

33 til melodien "Hvad kan os komme til for nød", der anvendes 15 gange af Ernst.

34 Denne salme er fra reformationstiden og kan næppe tillægges Jan Hus, men tilskrives ham undertiden sidst i 1600-tallet. Således i Daniel Paullis Dend Siungende Guds-Fryct, 1680, s. 468, og i Kingos Gradual, En Ny Almindelig Kirke-Salmebog, Odense 1699 blad R $1 \mathrm{v}$ og i nogle tidlige udgaver af Kingos salmebog.

35 Ernst citerer ikke fra Pontoppidan pietistiske salmebog fra 1740, der skriver "den mordere". Ernst læser "den mordener" ligesom reformationstiden salmebøger og Kingos salmebog. Således også i Paullis Dend Siungende GudsFryct, 1680, der betegner salmen med Luthers initialer D.M.L

36 Fink 2010, s. 22.

37 Fink 2010, s. 21; Thrap 1908, s. 6, 12-14, $36,65-66$.

38 Øverland 2005, s. 39.

39 Thrap 1908, s. 11 og 13

40 til melodien "Hvad kan os komme til for nød".

\title{
Zusammenfassung
}

Bisher hat man gemeint, die Glaubenserweckungen auf der Insel Alsen hätten erst ungefähr 1770 stattgefunden. Aber ein Buchfund auf einer Mülldeponie in Guderup auf Alsen hat diesen Zeitpunkt um einige Jahrzehnte verschoben. Ein Sammelband mit drei unbekannten herrnhutischen Schriften aus den Jahren 1755-56 von einem unbekannten Dichter namens Peter Ernst, wohnhaft in der Gemeinde Ketting auf Alsen, gibt wertvolle Einsichten in die religiöse Entwicklung und der schliesslichen Bekehrung des sechsundzwanzigjährigen Mannes im Jahre 1744. Er erlebt eine wundersame Klärung aus dem reuigen und niederdrückenden Pietismus zu einem fröhlichen Herrnhutismus. Eine zuvor nicht bewusste Fähigkeit als Dichter wird erlöst, und ein Tsunami von blutigen und ausgelassenen herrnhutischen Liedern spritzt aus seinem Gänsekiel. Er betrachtet seine blutigen Lieder als lutherisch berechtigt. Die Melodiehinweise auf seine ungefähr 180 Lieder beziehen sich zumeist auf die alte dänische Liedertradition und nur sieben auf das Liederbuch der Brüdergemeinde. Er berichtet über eine Verbindung zu gleichgesinnten Brüdern und Schwestern, sogar in Norwegen, die seine Lieder mit Dankbarkeit entgegengenommen haben.

Eine Ausgabe der ganzen Verfasserschaft ist zur Herausgabe im Jahr 2018, dem 300. Jahr seit seiner Geburt 1718, unter Vorbereitung.

\section{Fra helgenbillede i Kevelaer til kistebillede i Haderslev}

\author{
Et eksempel på konfessionelt betingede \\ ændringer af et billede ${ }^{1}$
}

Af Helge Clausen

I Haderslev findes to varianter af et religiøst billede fra slutningen af 1700-tallet af Jomfru Maria og Jesusbarnet. De befinder sig henholdsvis i den katolske Sankt Marie Kirke og i Museum Sønderjylland. Det kan påvises, at billedet stammer fra et andagtsbillede fra 1642 i den tyske valfartsby Kevelaer. I analysen og fortolkningen af billedet inddrages derfor elementer af den katolske teologi om Jomfru Maria. Kevelaerbilledet må være blevet indført til Haderslev, men før det blev genudgivet her, har det undergået visse forandringer for ikke at komme i konflikt med den lutherske teologi. Der sammenlignes med eksempler på kirkelige tekster og kirkekunst, som har været igennem den samme procedure.

\section{Indledning}

Trykte billeder fra tiden mellem reformationen og Grundloven i 1849 af Jomfru Maria med Jesusbarnet, hvor der forekommer tydelige katolske symboler, er usædvanlige på vore breddegrader. Der findes dog en del sådanne billeder, der ovenikøbet er trykt i det lutherske Danmark, som på den tid reagerede på næsten alt katolsk med skepsis, afvisning og forbud. Hvordan kan det så være, at billeder med tydeligt katolsk indhold ikke blot fandtes i den danske konges riger og lande, men også blev trykt her?

I et forsøg på et besvare dette spørgsmål bliver et bestemt billede af denne type analyseret med henblik på en fortolkning i lyset af dets historiske og kulturelle baggrund. Billedet, som er trykt i Haderslev og foreligger i flere varianter, undersøges for at fastslå dets ægthed og oprindelse. Dele af den katolske teologi om Jomfru Maria og den kirkehistoriske situation i det 17. og 18. århundrede i Nordeuropa inddrages som forståelsesramme.

Ud over de to eksemplarer af billedet, som i dag befinder sig i Haderslev, udgøres kildematerialet af breve mellem den danske folkemindeforsker, Johannes Evald Tang Kristensen og samleren af kistebilleder, 
V.E. Clausen, ligesom der er flere kopier af lignende danske og tyske andagtsbilleder. Endelig er en tysk forhørsprotokol fra 1647 benyttet. De anvendte kilder analyseres med henblik på at vurdere billedernes troværdighed.

Litteraturen om kistebilleder er ikke særlig omfattende, specielt ikke i Danmark. En litteratursøgning har kun givet få, relevante resultater. Haderslevbillederne har ikke tidligere været genstand for en nøjere undersøgelse.

\section{Baggrund: Den kirkelige billedkunst}

Siden Oldkirken har kunstneriske fremstillinger spillet en stor rolle i kristenheden. Man har ikke blot afbildet Kristus, Jomfru Maria og andre helgener, men også kristne symboler og scenarier. Der er tale om både plastiske - det vil sige krucifikser, statuer og relieffer - og grafiske fremstillinger, f.eks. ikoner, mosaikker, kalkmalerier, bogmalerier, oliemalerier og trykte billeder.

Da man i 1300-tallet begyndte at masseproducere trykte billeder, var det især helgenbilleder og spillekort, der blev trykt. Kirken tog hurtigt denne metode $\mathrm{i}$ brug for at kunne nå ud med sit budskab til de mange, der ikke kunne læse. Allerede 700 år tidligere havde pave Gregor den Store (590-604) fremhævet, at hvad skriften var for de lærde, var billedet for dem, der ikke kunne læse. ${ }^{2}$

Nogle religiøse statuer og billeder er blandt katolikker blevet genstand for særlig opmærksomhed: De troende har bedt den afbildede helgen om forbøn for et eller andet anliggende. Hvis der efterfølgende er sket uforklarlige eller mirakuløse bønhørelser, f.eks. i form af helbredelser, har det ofte medført, at et kultsted for den pågældende helgen er blevet oprettet. Derefter har pilgrimme besøgt stedet, enkeltvis og på valfarter. Sådan har det været siden kristendommens første tid. Blandt de grafiske fremstillinger indtager de såkaldte kistebilleder en særlig plads, og de to billeder fra Haderslev er netop sådanne kistebilleder.

\section{Hvad er et kistebillede?}

Et kistebillede er et håndkoloreret, illustreret etbladstryk, som blev fremstillet fra senmiddelalderen til midten af 1800-tallet. Det skete oftest ved hjælp af trykplader af træ - de såkaldte træsnit. Billedet, der normalt er ca. $31 \times 42 \mathrm{~cm}$, har næsten altid en forklarende tekst. Nav- net "kistebillede" stammer fra skikken med at klæbe dem fast på indersiden af standkisters låg. Der var også mange, der blev hængt op på væggen i almuehjem, med eller uden ramme. De fandtes i de fleste europæiske lande, de blev massefremstillet, og de var billige. Kistebillederne var i flere århundreder den mest udbredte form for billedkunst, som den almindelige befolkning ejede. ${ }^{3}$ De blev ikke regnet for ret meget i samtiden, men de er forholdsvis sjældne i dag.

I Danmark blev der fremstillet kistebilleder i perioden fra omkring 1650 til 1870, og i Det Kongelige Bibliotek er der en samling på 231 kistebilleder. Der er desuden en del kistebilleder i andre biblioteker, arkiver og museer, ligesom private samlere har et ukendt antal.

Kistebilledernes motiver kan bl.a. være bibelske, kirkehistoriske, historisk-politisk-sociale, satiriske eller moraliserende. Billederne er holdt i en naivistisk stil, og den håndpåførte farvelægning er ikke udført særligt omhyggeligt. De er ofte forsynet med en overskrift, der angiver billedets indhold. De følgende eksempler viser nogle 1700-tals kistebilleders temaer, som de blev formuleret dengang: "Det stedsevarende gudelige stueur", "De danske bønders frydesang over deres frihed fra stavnsbåndet" og "Kællingemøllen". 4

De fleste hjemlige kistebilleder blev enten fremstillet i Tyskland eller i Danmark efter tysk forlæg. I nogle tilfælde solgte tyske trykkerier deres trykplader af træ, kaldet stokke, til udenlandske trykkerier, og på den måde kunne et motiv flytte fra ét land til et andet. Der foregik også en omfattende kommerciel piratkopiering. Både de lovligt og de ulovligt trykte billeder blev i nogen grad ændret, enten for at tilpasse billedet til de lokale anskuelser eller for at sløre oprindelsen, og teksterne blev normalt oversat. Billederne blev solgt direkte fra trykkerierne, men i store byer kunne de også købes hos datidens boghandlere. Rejsende boghandlere fra Nordtyskland bragte dem til danske markeder, og danske kvægdrivere købte billeder i Tyskland for at sælge dem hjemme. ${ }^{5}$

Mange af de danske kistebilleder med religiøse motiver har rødder i det katolske udland. V.E. Clausen (1908-1989), der om nogen har samlet og studeret kistebilleder herhjemme, beretter f.eks., at et kistebillede med en lang tekst, hvor Gud bebrejder menneskene deres lunkne tro, stammer fra Den katolske Kirkes langfredagsliturgi. Teksten, som kaldes "improperierne" - bebrejdelserne - har i forskellige versioner været anvendt siden 600-tallet. V.E. Clausen skriver: "Således fortæller et gammelt ark om almuens stædige vedhængen ved katolsk andagtsstof flere hundrede år efter reformationen." 
Denne iagttagelse er interessant, idet det er velkendt, at forskellige katolske skikke, som reformatorerne fra 1520'erne energisk arbejdede på at afskaffe, kun modvilligt og langsomt blev opgivet af "almuen". Det drejer sig f.eks. om helgendyrkelse, valfarter, kildebesøg og brugen af visse bønner. Hertil kom naturligvis også den teologiske og liturgiske nyorientering, som reformatorerne stod for, og som ikke med ét slag ændrede folks tro. Man må også huske, at det var forbudt for danskere at være katolikker, huse katolikker osv. i den efterreformatoriske tid, indtil religionsfriheden blev indført med Grundloven i 1849. I den periode prøvede censuren at holde al katolsk påvirkning ude af landet, hvad trykte materialer angik. ${ }^{7}$ På den baggrund er produktionen i Danmark af billeder med tydeligt katolsk indhold bemærkelsesværdig. ${ }^{8}$

Fra de danske trykkerier kom der ikke blot billeder af Jomfru Maria og Jesusbarnet, men også en del andre religiøse billeder, som har tydelige katolske forlæg. Der er f.eks. et billede med Jesu lidelseshistorie, som bygger på de 14 korsvejsstationer, franciskanerne indførte i Jerusalem i 1300-tallet, og som derefter bredte sig til de fleste katolske kirker i alle lande. Her er der flere elementer, der ikke har direkte belæg i Bibelen, bl.a. mishandlingen af Jesus på vej til Golgatha, hvilket stammer fra en af Birgitta af Vadstenas (1303-1373) visioner. ${ }^{9}$ Eller et moraliserende københavnsk billede med "den gudfrygtige tjenestepige Susanna", hvor der på billedet optræder en munk med rosenkrans. Både munke og rosenkranse var uønskede af reformatorerne. Der findes et billede af Treenigheden, hvis katolske forlæg viser Jomfru Marias himmelkroning, hvilket mildest talt ikke er et luthersk anliggende. Det ovennævnte "stedsevarende gudelige stueur" fordeler Jesu sidste tid før korsfæstelsen på en række scener, der følger urets gang. Her anvender det katolske forlæg ikke en timeinddeling, men en inddeling i døgnets syv tidebønner. På den måde viser vesper, ca. kl. 18, Den sidste Nadver; komplét, ca. kl. 21, Jesu bøn i Gethsemane Have og slutter med tidebønnen non ved 15-tiden, hvor Jesus dør på korset. ${ }^{10}$

\section{Haderslevbilledet}

Grundlæggeren af Haderslevs første bogtrykkeri, Hinrich Luckander, blev født i Stockholm i 1716. Han kom via Flensborg til Haderslev og ansøgte i 1758 om tilladelse til at oprette et bogtrykkeri, hvilket blev bevilget året efter. Efter først at have boet på Klosteret købte han i 1764 en ejendom i Storegade, hvor han indrettede sit bogtrykkeri. Her blev der trykt mange bøger, tryksager, kistebilleder og skillingstryk. De fleste var uden angivelse af trykkeår, men med trykkested og nogle også med hans navn. Man kender 14 forskellige kistebilleder fra hans trykkeri, og de er alle med dansk tekst, hvilket i øvrigt gælder hovedparten af hans produktion. ${ }^{11}$ Luckander, som havde mange kunder i det meste af Jylland og på Fyn, døde 1796, men solgte 1793 trykkeriet til sin svend, Jens Jensen Seneberg, som drev det til 1829.

Ifølge V.E. Clausen ${ }^{12}$ findes der to varianter af Haderslevbilledet, som er trykt i den periode, Luckander ejede trykkeriet (1759-1793) og to fra Senebergs tid (1793-1829). Desuden blev motivet trykt af Thiele, der var virksom 1770-1815 i København. Ét af disse tryk befinder sig i dag på Norsk Folkemuseum, og der kendes fire i Danmark, heraf ét med tysk tekst, samt seks fra andre københavnske trykkerier. ${ }^{13}$ En anden variant kendes fra Sverige, hvor det blev trykt i Karlshamn i $1838 .{ }^{14}$ Kistebilleder udkom ofte i flere udgaver og oplag, som kan være meget vanskelige at skelne fra hinanden. De håndpålagte farver giver desuden mange varianter mht. farvevalg og udførelse.

Nederst på figur 1 står der: "Haderslev, trykt og at bekomme [erhverve] hos $\mathrm{H}$. Luckander", og der er et håndskrevet tal 1787 i nederste venstre hjørne. Denne oplysning findes kun på dette ene eksemplar. Tallet kunne godt være trykkeåret. Tilsvarende står der nederst på figur 2, at det er Seneberg, der har trykt det, og at det er ham, der sælger det. Bortset fra farvelægningen er der ingen forskelle på de to tryk. De må være fremstillet med den samme trykstok, hvor nederste linje er blevet tilrettet, idet de har en hel række småfejl tilfælles. Der kendes seks eksemplarer fra Luckander, et fra Seneberg og to fra "bogtrykkeriet i Haderslev". Desuden kender man som nævnt en halv snes eksemplarer med samme motiv fra københavnske trykkere. ${ }^{15}$

Der er næsten ingen dybde i billedet. De centrale figurer, Jomfru Maria med Jesusbarnet, er omgivet af en strålekrans og dekorative blomsterranker, hvoraf nogle vokser op af to vaser. Maria står på en lav forhøjning, og hendes fødder med sko er alt for små. Hun bærer en vid, stiv spansk kappe, ${ }^{16}$ og en prægtig stiv barokkjole med borter. Hendes hår er ikke synligt, men på hovedet har hun et hovedlin [tørklæde] og bærer en åben barokkrone med fem stjerner over. ${ }^{17}$ Kronen symboliserer den katolske opfattelse af, at Maria efter sin død og optagelse i Himlen blev kronet som Himlens Dronning. Hun bærer en enkel, treradet halskæde. I højre hånd holder hun som scepter en lilje, der symboliserer jomfruelighed. Maria holder om Jesusbarnet med venstre arm, 


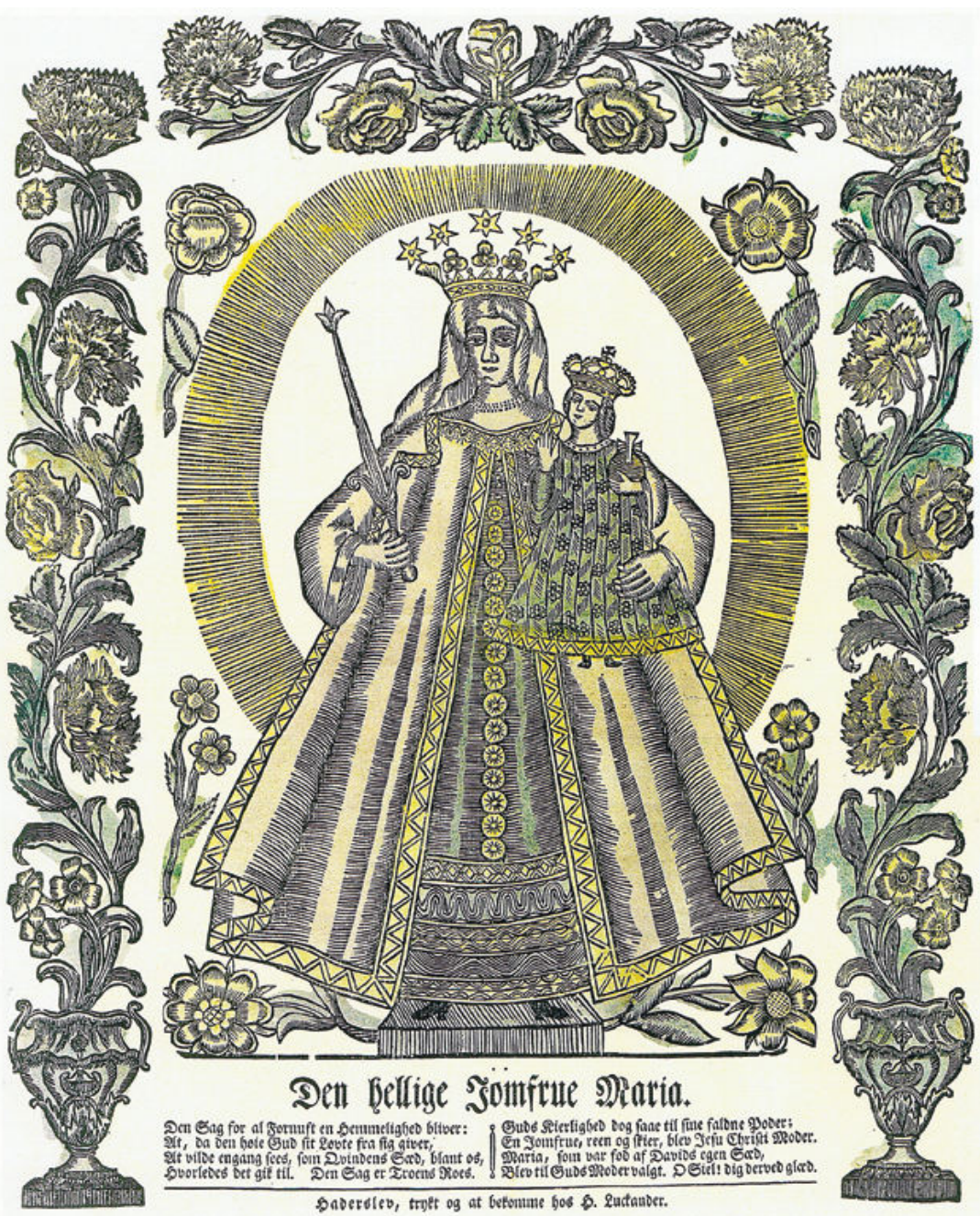

Figur 1: Luckanders "Den Hellige Jomfrue Maria". Kistebillede fra før 1794. Sct. Ma rie Kirke, Haderslev. Skænket kirken i 2008.

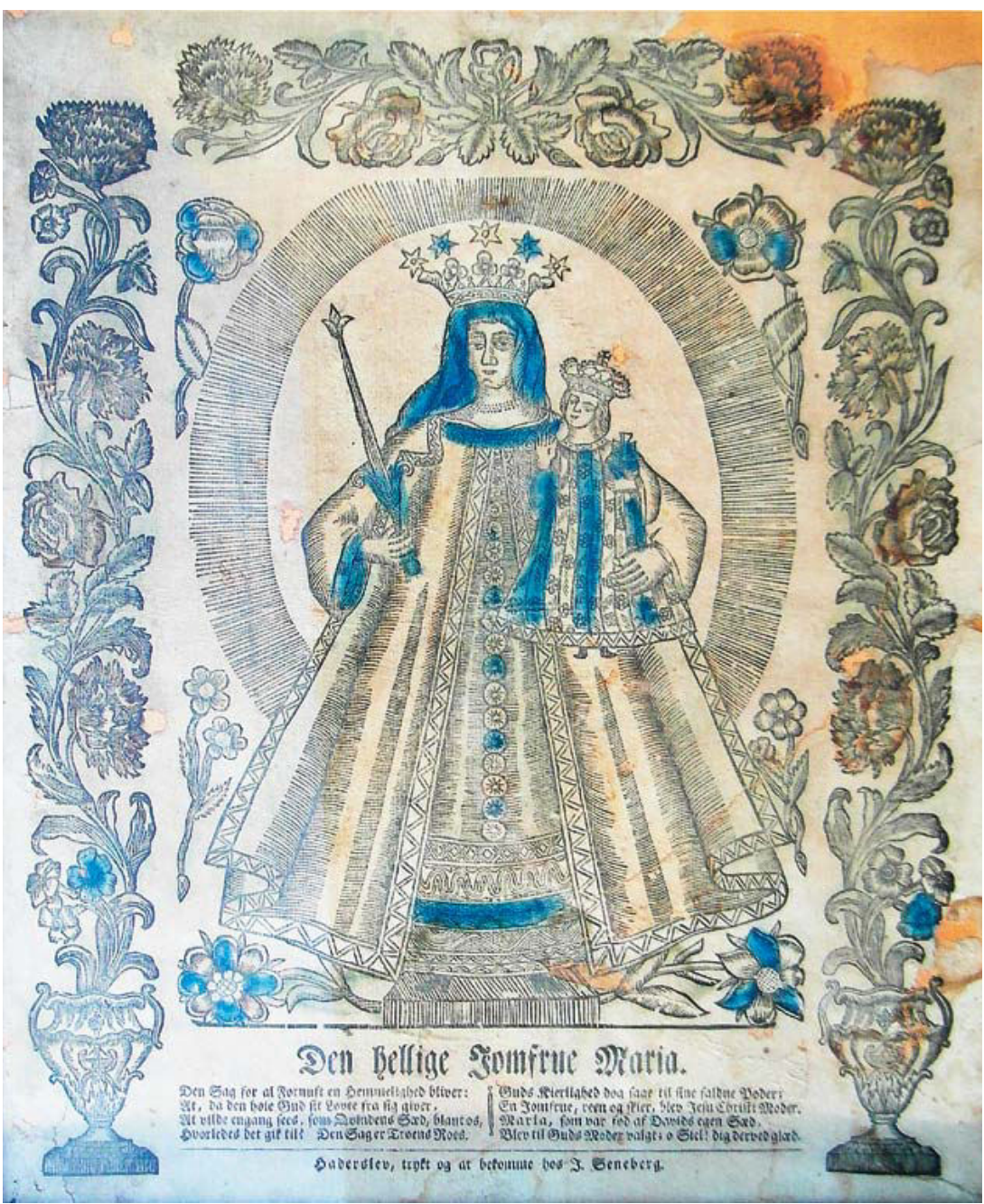

Figur 2: Senebergs "Den Hellige Jomfrue Maria". Kistebillede fra efter 1792. Museum Sønderjylland - HAM 999x2769. Det blev indleveret til museet før 1905, sandsynligvis fra Haderslev By eller Amt. Foto: Lennart S. Madsen. 
men holder ham ikke ind til sin krop; det er, som om han svæver. Han er fremstillet i stående stilling og har også meget små fødder og sko. På hovedet bærer han en lukket bøjlekrone. Anvendelsen af denne som kongekrone var en europæisk skik, der først vandt indpas i Danmark i løbet af 1600-tallet. I venstre hånd har han et rigsæble med kors, som også er et kongeligt værdighedstegn, og højre hånd holdes frem i en hilsende gestus. Han bærer en lang dragt, som er udsmykket med lodrette rækker af blomster og afsluttes med en bort forneden.

Forneden står med store typer: "Den hellige Jomfrue Maria" og herunder er der to vers:

"Den sag for al fornuft en hemmelighed bliver:

At, da den høje Gud sit løfte fra sig giver,

At ville engang ses, som kvindens sæd, blandt os,

Hvorledes det gik til. Den sag er troens ros.

Guds kærlighed dog så til sine faldne poder;

En jomfru, ren og skær, blev Jesu Christi moder.

Maria, som var født af Davids egen sæd,

Blev til Guds moder valgt. O sjæl! dig derved glæd."

De ovennævnte versioner fra København og Karlshamn af billedet har andre vers, men i samme stil. Versenes forfatter lader sig ikke identificere. Mange præster kunne skrive sådan dengang. Det kan også være en lærer eller en degn, eller måske en opvakt typograf, som gik i kirke? Det er alexandrinske vers, hvor verselinjerne er 6-fodsjamber. Det betyder, at hver en kort stavelse efterfølges af en lang, samt med cæsur [ophold] i midten og enderim. Versene er ikke beregnet til at skulle synges. Ingen danske salmer eller åndelige sange er skrevet på alexandrinere, som ellers var på mode i Danmark fra ca. 1630 og et par hundrede år frem. Rimet "poder" - "moder" i andet vers virker lidt anstrengt og er et såkaldt nødrim, så "moder" kan bruges. "os" - "ros" i første vers er heller ikke for godt.

Teksten er ren bibelsk frelseshistorie - altså en guddommelig plan hentet fra Bibelen - og til trods for motivet, er der ingen elementer fra den katolske Mariadyrkelse. Der er f.eks. ingen anråbelse om forbøn eller anvendelse af Marias titler. Blot fordi "Maria" nævnes, behøver det ikke at være et udtryk for katolsk Mariadyrkelse, hvilket blandt andet kommer til udtryk i Kingos salme: "Nu kom der bud fra englekor", hvor "Maria" er nævnt to gange og i øvrigt omtales som "livsaligste blandt Evas køn". Kingo havde bestemt ingen katolicerende tendenser, tværtimod var han - som næsten alle lutheranere på den tid - kendt som en skrap antikatolsk protestant. Han klagede eksempelvis til kong Christian V over en katolsk præst fra Fredericia, som her lovligt måtte tage sig af udenlandske katolikker, der havde besøgt katolikker på Fyn. Kongen lod præsten kaste i fængsel i ti dage. ${ }^{18}$

Det er svært at se andre motiver end rent forretningsmæssige hos Luckander, da han trykte dette billede, der var populært i udlandet, og forsynede det med en relevant og letforståelig tekst. Der er tale om en protestantisk Mariafromhed, hvor teksten teologisk set holder sig på dansk, luthersk grund. Men Marias krone og scepter samt strålekransen er katolsk.

\section{Hvor stammer motivet oprindeligt fra?}

Hvordan kan det være, at man trykte og solgte et billede med så tydelige katolske elementer i det protestantiske Danmark?

Jomfru Maria var faktisk en del af folkefromheden flere hundrede år efter reformationens indførelse. Hun optræder ofte i fremstillinger af de bibelske beretninger om bebudelsen, besøget hos Elisabeth, Jesu fødsel i stalden, flugten til Ægypten og korsfæstelsen. For Luther var Maria dog alene et forbillede på ydmyghed. Protestanterne tolererede derfor billeder af Maria, men tog generelt afstand fra hendes dronningeværdighed og hendes og andre helgeners forbøn, hvilket heller ikke optræder i billedernes tekster. Maria, der bliver kronet i Himlen af de tre personer i Treenigheden, ses dog på en del førreformatoriske altertavler i de danske kirker. Dem har man ikke fjernet, selv om det teologiske budskab var alt andet end luthersk. ${ }^{19}$ Man har nok valgt at fokusere på Treenigheden. Men én ting er at bevare en gammel altertavle, hvor der kunne sættes spørgsmålstegn ved visse elementer. Noget andet er at fremstille noget nyt, der var religiøst ukorrekt.

Det er blevet påvist, at forlægget til dette kistebillede kom fra en katolsk egn i Tyskland, og at det blev tilrettet af det danske trykkeri, så det ikke længere udsendte helt så tydelige katolske signaler, for derefter at blive trykt i mange eksemplarer over en længere årrække.

Bibliotekaren og folkemindeforskeren Johannes Evald Tang Kristensen (1906-1994) offentliggjorde i 1941 en større oversigt over danske kistebilleder. $^{20}$ I 1946 blev han kontaktet af kistebilledsamleren V.E. Clausen, der gjorde opmærksom på sin samling på ca. 85 kistebilleder. 
Han omtaler i sit brev, at "det ældste, et Augsburgbillede fra Albrecht Schmidt, som har siddet i en dansk kiste, er et valfartsbillede fremstillende Sancta Maria. Det bærer en latinsk tekst, henvisende til valfartsbyen Kevelaer, og har årstallet 1647 [skal være 1649]. Det er af samme størrelse som de almindelige kistebilleder og træsnittet, der er i renæssancestil, er koloreret". ${ }^{21}$ I et senere brev gengiver Clausen alle dette kistebilledes tekster og bemærker, at det "behøver vel ikke at være lige fra året 1649, men er sikkert ikke meget yngre". ${ }^{22}$ Han tilbød, at Tang Kristensen kunne låne det og få det affotograferet. Clausen bemærker også, at der nok ikke kendes ældre kistebilleder i Danmark end dette. Det var en gammel snedker, der havde pillet det ud af en kiste og solgt det til en antikvar, hvorfra han fik det. Billedet har også givet ham anledning til undren: "For øvrigt er det forbavsende så mange helgenbilleder, der findes i kisterne 300 år efter reformationen". ${ }^{23}$ Denne bemærkning kan tages til indtægt for, at visse katolske traditioner, som for eksempel helgendyrkelse, ikke uden videre var forsvundet i Danmark, til trods for reformatorernes bestræbelser.

Efter kontakten med Clausen kunne Tang Kristensen i 1948 offentliggøre et stort supplement til sin artikel fra 1941. ${ }^{24}$ Her konstaterer han, at der ingen tvivl er om, at Augsburgbilledet er i familie med det tilsvarende fra Luckanders bogtrykkeri i Haderslev. Billedet er aftrykt i artiklen, men i en temmelig dårlig gengivelse. Det er lykkedes at finde forlægget til denne gengivelse, idet der i Tang Kristensen arkiv i Aalborg Stadsarkiv er et $\mathrm{s} / \mathrm{h}$ fotografi af det (figur 3). Originalen fra Clausens samling har ikke kunnet findes, heller ikke andre eksemplarer, hverken i Danmark eller Tyskland. Efter Clausens død i 1989 fik Dansk Folkemindesamling tilbudt at købe hans samling af kistebilleder. Det lykkedes ikke at skaffe de fornødne midler, og samlingen blev købt af museet på Gottorp Slot. ${ }^{25}$ Her har man beklageligvis ikke kunnet finde dette Augsburgtryk, som er meget sjældent. ${ }^{26}$

Ophavsmanden til billedet, Albrecht Schmidt, blev født ca. 1667 i Ulm og døde 1744 i Augsburg. ${ }^{27}$ Efter at have lært håndværket etablerede han sig 1694 i Augsburg som "formskærer og brevmaler" og blev en stor billedproducent. Han fremstillede mange træsnit, og hans trykstokke blev solgt til bl.a. Danmark. ${ }^{28}$ Også billeder fra Albrecht Schmidts eget trykkeri har været udbredt her i sidste halvdel af 1700-tallet. I Frederik $V^{\prime}$ s atlas fra omkring 1775 er der således en hel del af hans kolorerede billeder. Albrecht Schmidt har for øvrigt fremstillet flere forskellige versioner af Mariabilledet. ${ }^{29}$

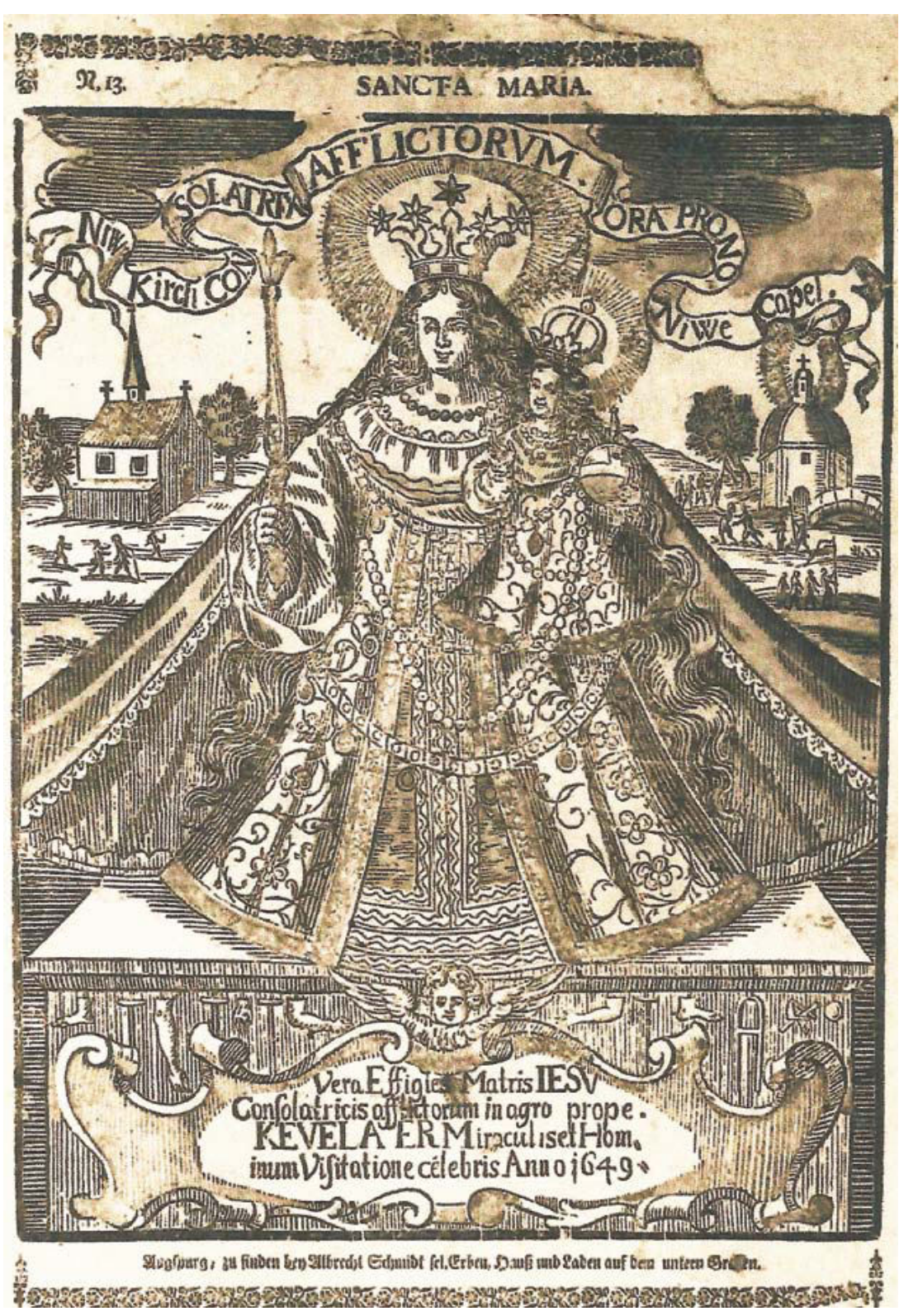

Figur 3.: Sancta Maria (s/h fotografi fra AaS, A2411, løbenr. 11). Trykt af Albrecht Schmidt i Augsburg efter 1744. 


\section{Sammenligning mellem Haderslev- og Augsburgbilledet}

Johannes Evald Tang Kristensen bemærker, at "Det danske tryk er langt grovere i udførelsen. Den landskabelige baggrund med kirke og kapel, og den i selve stokken skårne tekst i det tyske tryk er forsvundet. Det eneste fælles er linjerne i Maria og Jesus figurerne". ${ }^{30}$

På Augsburgbilledet, som er et kobberstik, er der langt flere detaljer. Maria har langt hår, der er jomfruens kendetegn og som når næsten ned til fødderne, en halskæde og tre ekstra kæder, hvoraf to også er omkring Jesusbarnet, heraf én med et kors. Hun har en rigere dekoreret klædning, som består af kjole, kappe og et ekstra fodlangt hovedlin, der er den gifte kvindes kendetegn. At Maria er udstyret med både en jomfrus og en gift kvindes kendetegn, afspejler den katolske opfattelse af hende som jomfru, både før og efter hun havde født sit eneste barn, Jesus, og som Josefs hustru.

Marias krone er et tegn på hendes værdighed som "Himmeldronning" og er blevet anvendt siden 500-tallet. ${ }^{31}$ Ifølge katolsk tro og lære blev Maria umiddelbart efter sin død optaget i Himlen og kronet som Himlens Dronning. ${ }^{32}$ I Det nye Testamente er "livets krone" lønnen til de trofaste og dem, der holder ud i prøvelser. ${ }^{33}$ Netop i 1600-tallet fik de kronede Mariafigurer en renæssance i de lande, der var præget af den katolske modreformation. Talrige Mariafigurer blev kronet i forbindelse med katolske fremstød. I katolsk sammenhæng har Maria forskellige titler, som karakteriserer hendes person og virke. Én af dem er "Jomfruernes dronning", der findes i det lauretanske litani, som er en samling på oprindeligt 49 korte bønner til Jomfru Maria. Litaniet kendes fra 1531, men har rødder tilbage til 1100-tallet. Der var mange kronede Mariafigurer i de danske kirker, også efter reformationen, selv om man havde gjort op med den katolske Mariadyrkelse. ${ }^{34}$ Kronerne fik i mange tilfælde lov til at blive i kirkerne, fordi de var så populære. Nogle blev også gemt og fundet senere. Det var en udbredt skik, at brude kunne låne eller leje kronen fra kirkens Mariafigur af præsten som brudekrone/ krans ved deres egne bryllupper. Da kronerne efterhånden forsvandt, begyndte man at anvende myrtekranse i stedet. ${ }^{35}$

Jesusbarnet, som hun bærer på venstre arm, holder højre hånd op i en velsignelsesgestus, hvilket ses af fingerstillingen, og ikke blot som en hilsen som på Haderslevbilledet. Både Maria og Jesus smiler og ser selvsikre ud, hvad de ikke gør på Haderslevbilledet, og deres hoveder er omgivet af strålekranse. Maria og Jesus er fremstillet på en mere "ophøjet" måde end på Haderslevbilledet, idet de er anbragt på et højt podium, en såkaldt plint, der er et fodstykke til en statue. Marias og Jesu fødder ses ikke som på figur 1 og 2, hvor de tydeligvis er tilføjet.

Der er ingen blomsterranker eller vaser, men et landskab med træer, bakker og en bro i baggrunden. Derved får man et mere tredimensionalt indtryk. Til venstre er der en kirke med spir, og fire mennesker er på vej mod højre side af billedet, hvor der er et sekskantet kapel med kuppel. Ved dette kapel er der tre grupper af personer, der går i procession med kors og faner. Pilgrimme og valfartsdeltagere er på vej mod kapellet, som må være et valfartskapel. På Haderslevbilledet har man også helt udeladt Augsburgbilledets baggrund med kirke, valfartskapel, pilgrimme, træer og tekster. Det identificeres i teksten nederst på billedet som beliggende i Kevelaer, der ligger i det nordvestlige Tyskland, tæt på grænsen til Holland.

På plintens forside er der - foruden en indskrift og en engel - ophængt en række genstande, bl.a. fem krykker, tre arme, to fødder og en hånd. Det er såkaldte votivgaver, som findes ved de fleste valfartssteder. De er blevet givet som tak fra personer, der har oplevet bønhørelse, og det kommer af ordet votum, som betyder højtideligt løfte. Fænomenet kendes også uden for katolske sammenhænge, f.eks. i form af nogle af de skibsmodeller, der er blevet skænket danske kirker, ofte som tak for redning til havs. Votivgaver er ellers et delvis ukendt og teologisk suspekt fænomen for protestanter, og derfor måtte de fjernes fra Haderslevbilledet.

Haderslevbillederne var trykt is/h, men blev farvelagt $\mathrm{i}$ hånden. Der blev anvendt op til fire farver, bl.a. rød, rosa, blå, gul, grøn og brun. Farvepålægningen er som nævnt ikke særligt omhyggeligt eller konsekvent udført, og virker ofte lidt tilfældig. Mange af de tyske kistebilleder var kobberstik, der havde farvetryk eller håndpålagte farver, som var meget mere omhyggeligt udført og vidnede om en mere avanceret teknik og højere kvalitet.

Teksterne på billedet er meget vigtige med henblik på en forståelse af dets indhold og formål:

Over billedet står der "SANCTA MARIA" - altså den hellige Maria - og på skriftbåndet øverst "Niwe Kirch CONSOLATRIX AFFLICTORUM. ORA PRO NO[BIS] Niwe Capel". Det betyder "Den nye kirke. DE BEDRØVEDES TRØSTERINDE. BED FOR OS. Det nye kapel". "Den nye kirke" ligger til venstre i billedet og "det nye kapel" til højre, begge i Kevelaer. Kirken var færdigbygget den 20. november 1645, men 
blev først indviet den 2. maj 1649, da Trediveårskrigen var slut. I dag kaldes bygningen "Kerzenkappelle" og anvendes hovedsagligt til at tænde votivlys. Kapellet, som er sekskantet, blev bygget i barokstil i 1654 og findes stadig, og det er her, billedet er anbragt. Udtrykket "De bedrøvedes trøsterinde" optræder også i det lauretanske litani som én af Jomfru Marias titler og har været et motiv for nogle kunstnere, f.eks. Rafael (1483-1520).

Teksten forneden lyder: "Vera Effigies Matris IESV Consolatricis afflictorum in agro prope KEVELAER Miraculis et Hominum Visitatione celeberis. Anno 1649". Det betyder "Sandt billede af JESU Moder, de bedrøvedes trøsterinde, på en mark nær ved KEVELAER, berømt på grund af mirakler og menneskers besøg. År 1649". Her optræder igen udtrykket "de bedrøvedes trøsterinde".

Under billedet er der trykt: "Augsburg, zu finden bey Albrecht Schmidt sel. Erben, Haus und Laden auf dem untern Graben". Altså: "Augsburg, kan findes hos den salige [afdøde] Albrecht Schmidts arvinger, hus og butik på Unterer Graben". Denne tekst dokumenterer billedets oprindelse og indikerer trykkeåret, idet det er efter Albrecht Schmidts død i 1744. Årstallet 1649 i billedteksten er således ikke trykkeåret, men henviser måske til indvielsen af den nye kirke.

Men vi er ikke færdige endnu. Augsburgbilledet, som blev forlæg for Haderslevbilledet, var ikke det egentlige mål for valfarterne. Det var et andet billede, "Kevelaerbilledet", der gav anledning til, at Kevelaer blev et mariansk kultsted, som har været mål for valfarter fra 1640'erne til i dag. Men hvordan gik det til?

\section{Kevelaer}

Kevelaer ligger 70 km nordvest for Düsseldorf, tæt ved grænsen til Holland. Byen, som har ca. 30.000 indbyggere, er et kendt, katolsk valfartssted, der årligt besøges af ca. en mio. mennesker. Forhistorien er den, at hen mod jul 1641 kom den fromme handelsmand Hendrik Busman til et vejkors ikke langt fra byen. På den tid var Kevelaer kun en lille fattig flække. Han hørte en stemme, som opfordrede ham til at oprette et vejkapel på dette sted. Den samme oplevelse havde han med nogle dages mellemrum to gange mere på samme sted.

Nogle måneder senere fik hans hustru, Mechteldt Schrouse, tilbudt at købe et andagtsbillede på papir, der forestillede den $73 \mathrm{~cm}$ høje statue "Vor Frue af Luxemburg" fra begyndelsen af 1600-tallet, der er i
Domkirken i Luxemburg. ${ }^{36}$ Hun syntes, prisen var for høj, men en nat havde hun en vision, hvor hun så et vejkapel med netop dette billede. Det lykkedes hende at efterspore billedet og købe det. Efter at parret havde sparet penge sammen, blev der bygget et lille vejkapel, og den 1 . juni 1642 blev andagtsbilledet opsat i det af den lokale præst. Billedet var et lille kobberstik på 7,5 x $11 \mathrm{~cm}$ af Jomfru Maria med Jesusbarnet på armen. Egnen havde lidt meget under Trediveårskrigen, og folk begyndte at komme til vejkapellet for at bede. Begivenhederne omkring oprettelsen af vejkapellet blev i 1647 indgående udredt og ført til protokols på en synode - et officielt kirkeligt møde - i den nærmeste større by, Venlo. ${ }^{37}$

\section{Nøgler til tydning af billedet: Trøst og forbøn}

Øverst på dette lille billede er der et skriftbånd med teksten "Consolatrix Afflictorum ora pro nobis", der betyder "De bedrøvedes trøsterinde, bed for os". Hvordan skal det forstås?

"Trøst" nævnes mange gange i Bibelen og hos kirkefædrene om Gud, som trøster menneskene. Ordets betydning ses af det tilsvarende latinske ord, con-solari, der kan oversættes med "at være sammen med én, der er alene". Begrebet forbindes også allerede fra 300-tallet med Jomfru Maria. Der findes flere end 40 valfartssteder i Europa, hvor Maria dyrkes som "de bedrøvedes trøsterinde". ${ }^{38}$

Forbøn er et grundlæggende element i den katolske troslære. De troende kan opnå bønhørelse i et eller andet anliggende, hvis det er Guds vilje. Særligt vigtig for katolikker er helgenernes forbøn, især Jomfru Marias. I historiens løb har anråbelse om Marias forbøn efter mange katolikkers oplevelse og tro ført til bønhørelse i små og store anliggender. De små kan være dagliglivets problemer og de store, f.eks. hvis den kristne tro og kultur blev truet af kættere eller af andre religioner. Det gælder f.eks. i forbindelse med billedstriden ${ }^{39}$ i 700 -tallet, ved slaget ved Poitiers i 732, hvor Karl Martel standsede saracenernes invasion; ved korstoget mod albigenserne i 1100- og 1200-tallet; under søslaget ved Lepanto i 1571, hvor en overtallig osmannisk flåde blev slået af Den hellige Liga; i slaget ved Det hvide Bjerg ved Prag i 1620, hvor Den protestantiske Union blev slået af Den katolske Liga; ved forsvaret af klosteret Jasna Góra i Częstochowa mod svenskerne i 1655 og svenskernes tilbagetrækning fra hele Polen to år senere; under slaget ved Wien i 1683, hvor osmannerne blev slået af en hær fra flere katolske lande, 
og ved det såkaldte "Mirakel ved Wisła [Vistula]", hvor en undertallig polsk hær mod alle odds i 1920 drev Den røde Hær på flugt. ${ }^{40}$ De fleste af disse eksempler på bønhørelse på Marias forbøn er - omend på forskellige måder - blevet anerkendt af de katolske kirkelige myndigheder.

Dette er en væsentlig del af baggrunden for oprettelsen af nye Mariavalfartssteder i de områder, der var gået tabt for Den katolske Kirke efter reformationen. Sådanne valfartssteder blev ikke oprettet i flæng, men kun på steder, hvor der var anledning til det. Det var oftest tilfældet, hvor man havde oplevet et mirakel på Marias forbøn, eller hvor mennesker rapporterede at have haft en mariansk åbenbaring eller vision. Hvis det så viste sig, at der begyndte at komme pilgrimme til stedet, og der var tale om flere bønhørelser, blev der foretaget kirkelige undersøgelser. Hvis de stedfundne hændelser blev fundet troværdige, gik Kirken officielt ind og støttede opbygningen af et valfartssted med kirker og andre bygninger, præster mv. Det var tilfældet i Kevelaer og flere andre steder i Nordeuropa. Modreformationens katolske "elitetropper" var jesuitterne, som også fremmede Mariadyrkelsen meget. I kraft af de stedfundne bønhørelser blev billedet nu betragtet og omtalt som "nådebilledet fra det og det sted", f.eks. Kevelaer, fordi de mennesker, der havde ment sig bønhørt her, havde fået del i Guds nåde. Luther anerkendte kun ét nådebillede, og det var af korsfæstelsen. ${ }^{41}$

Man kan kort sige, at Marias forbøn og dele af Mariadyrkelsen var og er et af Den katolske Kirkes vigtigste "åndelige våben" i kampen mod det onde og dem, der vil den til livs. Det udtrykkes kort og kontant i en linje, der stammer fra 700-tallet, der bl.a. anvendes som antifon, som er et slags omkvæd, i Det romerske Breviar: "Gaude Maria virgo, cunctas haereses sola interemisti in universo mundo", der betyder "Glæd dig, Jomfru Maria, for du alene har tilintetgjort alle kætterier i hele verden". ${ }^{42}$

Denne inddragelse af Maria som "åndeligt våben" kom særligt til udtryk efter reformationen. Således stillede stifteren af jesuiterordenen, Ignatius af Loyola, sin orden i "Marias tjeneste". De jævne katolikker sluttede op om dette ved at deltage i valfarter til Marias ære. Det er ikke noget tilfælde, at valfarten til Vor Frue af Luxemburg begyndte i 1624 midt under Trediveårskrigen, hvor mange bad om, at krigen måtte holde op. Andagtsbilledet af Vor Frue af Kevelaer blev meget udbredt og motivet blev ikke alene trykt i talrige udgaver, men kan også ses på prydtallerkener, bageforme med spejlvendt skrift, tobaksdåser, sølvtøj fra skyttelaug og møbler. ${ }^{43}$ Udbredelsen af billedet på alle disse måder bidrog til at aktivere lægfolket, intensivere deres religiøse praksis og udbrede kulten.

På vore breddegrader blev sådanne billeder bl.a. til kistebilleder. Det var også af og til tilfældet på vort billedes hjemegn. Fra Kevelaers omegn har man et eksempel på en dragkiste, der ofte indeholdt alle et tyendes ejendele, som på det opslåede lågs inderside er fyldt med kistebilleder. Et af dem er en kopi af billedet fra Kevelaer. Desuden er der et billede af korsfæstelsen og nogle helgenbilleder. Ved dette "husalter" har ejeren kunnet holde sine andagter og daglige bønner og bl.a. bede om Jomfru Marias forbøn. ${ }^{44}$ Om noget sådant har fundet sted i Danmark er uvist, men man må formode, at religiøse billeder i almindelighed er blevet anvendt ved personlige andagter $\mathrm{mv}$.

\section{Kevelaerbilledets oprindelse}

Augsburgbilledet af Albrecht Schmidt og alle andre billeder fra Kevelaer med samme motiv er imidlertid ikke helt identiske med det originale Kevelaerbillede, som Mechteldt Schrouse købte i 1642. Det forestiller nemlig statuen "Vor Frue af Luxemburg" ${ }^{45}$ Kevelaerbilledet er i dag noget medtaget af tidens tand, men kan godt reproduceres, som det er gjort i figur 4 . Det er lige fra 1642 til vore dage blevet gengivet i talrige versioner.

Sammenlignet med Augsburgbilledet (figur 3) er der tre vigtige forskelle:

1. Foroven til venstre er der ikke en "ny kirke", men del af en større by med fire kirketårne, bymur og byport. Oven over tårnene er der på figur 4 anført navnet på byen, nemlig "Luxemburg".

2. Indskriften forneden, som lyder: "Vera Effigies Matris IESU Consolatricis afflictorum in agre suburbano Luxemburgi Miraculis et Hominum Visitatione celebris Anno 1640". Det betyder "Sandt billede af JESU Moder, de bedrøvedes trøsterinde, på en mark uden for Luxemburg, berømt på grund af mirakler og menneskers besøg. År 1640".

3. Tilbygningen med de to tårne ved kapellet foroven til højre. Sådan var det valfartskapel, som dengang lå lige uden for Luxemburg på byens glacis - det skrånende terræn foran en fæstning - hvor statuen "Vor Frue af Luxemburg" befandt sig. Kapellet blev bygget 1625, udvidet 1640 og ødelagt $1795 .{ }^{46}$ 


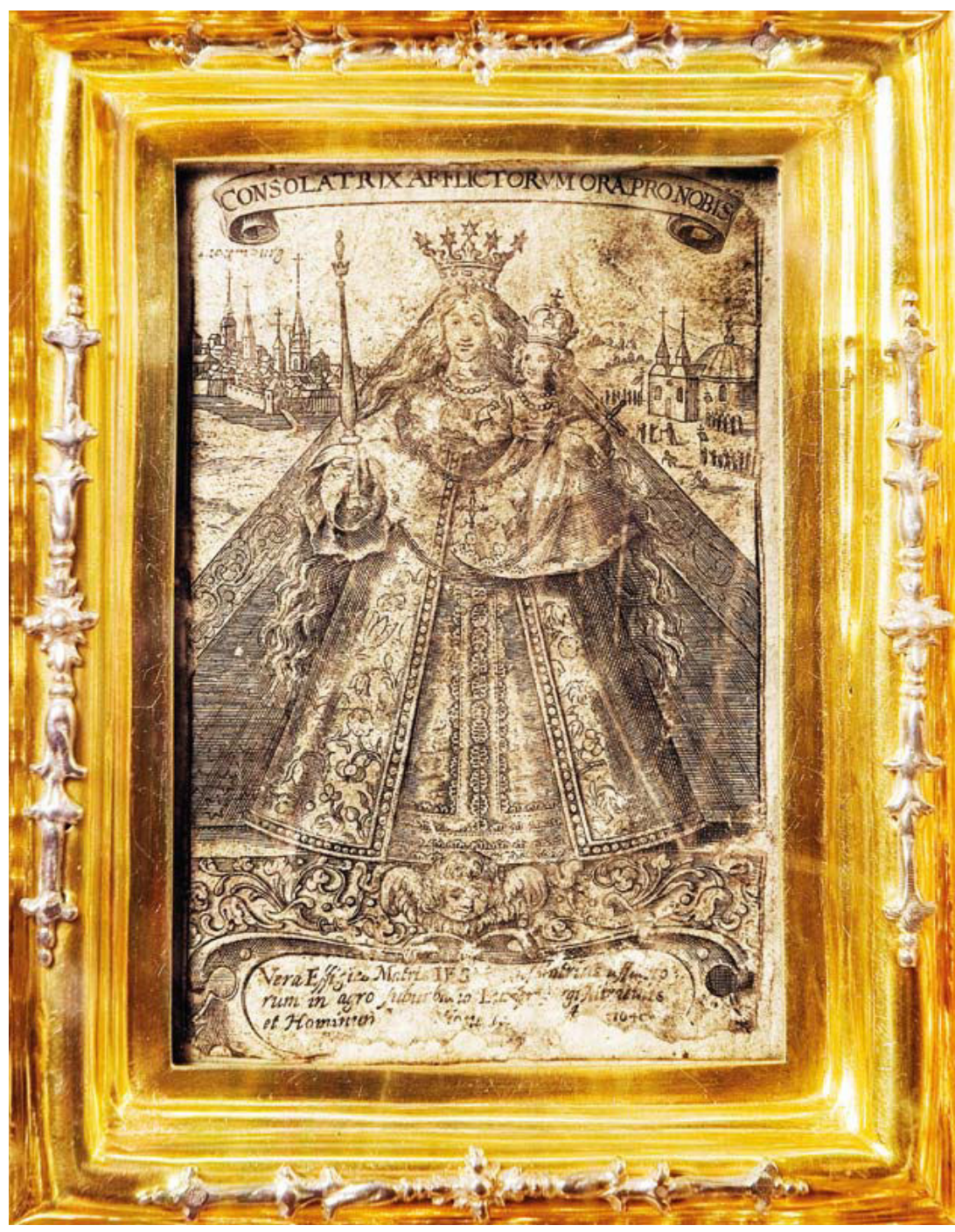

Figur 4: Kevelaerbilledet (original). Gengivet med tilladelse fra Pfarrgemeinde, St. Marien Kevelaer/Wallfahrtsleitung.
Vi kan nu kort opsummere billedets historie:

1642: Kevelaerbilledet. Et billede fra 1640 af statuen "Vor Frue af Luxemburg" blev genstand for andagt i Kevelaer (figur 4).

Efter 1744: Augsburgbilledet. Albrecht Schmidts efterfølger fremstillede en version af Kevelaerbilledet (figur 3) og måske også en eller flere versioner før 1744.

Mellem 1759 og 1794: Haderslevbilledet. Luckanders version (figur 1) af Albrecht Schmidts billede, som også blev fremstillet af Seneberg efter 1792 (figur 2). Nogle versioner blev også trykt i København og andre steder på denne tid.

Hvordan kom billedet fra Kevelaer til Haderslev?

I Vadehavet ca. $20 \mathrm{~km}$ nordvest for Husum ligger halvøen Nordstrand. Før den store stormflod i oktober 1634 var Nordstrand en ø. Der druknede flere end 6.000 mennesker under stormfloden "den store mandedrukning", som ødelagde en snes landsbyer og 17 kirker. For at standse havets fortsatte ødelæggelse af det frugtbare land indkaldte hertug Friedrich III af Gottorp i 1652 erfarne digebyggere fra Flandern og Brabrant. De var katolikker, og én af betingelserne for, at de ville komme var, at de fik religionsfrihed, hvilket der ellers ikke var lovhjemmel til hverken i Slesvig og Holsten eller i selve Danmark. Digebyggerne havde deres egne præster med, hvoraf de fleste tilhørte oratorianerordenen ${ }^{47}$ og var fra Mechelen. Endnu i vor tid er ca. 20\% af indbyggerne på Nordstrand katolikker mod ellers kun ca. 7\% i Slesvig-Holsten. ${ }^{48}$

Præster fra denne orden havde i 1646 overtaget sjælesorgen på valfartsstedet Kevelaer. Fra 1654 til 1860 var alle sognepræster på Nordstrand oratorianere, og der var en stadig udveksling af dem mellem Kevelaer og Nordstrand. Forbindelserne var så stabile og sikre, at man f.eks. under den franske revolution i 1789 fra Kevelaer i al stilhed sendte det vigtigste kirkelige udstyr - det vil sige alterkalke, kostbare messehagler mv. - og arkivalier i sikkerhed til den katolske kirke på Nordstrand. I 1793 var der mindst 13 præster i eksil på Nordstrand.

Det er højst sandsynligt, at præster fra Kevelaer medbragte kopier af nådebilledet fra Kevelaer til Nordstrand, hvor der findes et eksem- 
plar. ${ }^{49}$ Herfra var der handelsforbindelser nordpå. Det er derfor muligt, at omvandrende handelsmænd har set billedet på Nordstrand og har købt nogle kopier for at sælge dem derhjemme, f.eks. i Haderslev.

\section{Konklusion: En kopi og en original}

Forneden til venstre på billedet fra Sankt Marie Kirke står der "1787". Dette håndskrevne tal forekommer kun på ét andet kendt eksemplar af kistebilledet, nemlig Nationalmuseets, og er nok et årstal. ${ }^{50}$ I 1977 udgav Nationalmuseet 13 Skillings-tryk fra 1700- og 1800 årene i en mappe. Blandt disse 13 genoptryk er også Maria-kistebilledet, og årstallet 1787 er tydeligt at se forneden til venstre sammen med en trykt oplysning om, at Nationalmuseet har genudgivet det. Denne sidste oplysning er klippet fra i Sankt Marie Kirkes eksemplar. Nationalmuseets eksemplar har nogle små skader og en revne i papiret, som også findes i kirkens eksemplar. Konturerne på farvelægningen, som er udført i hånden, er ens i de to eksemplarer. En analyse af Sankt Marie-eksemplarets papir viser, at papiret er af nyere dato. Det er således glat og let gulnet, der er ingen spor efter trådnet, som der ville have været ved håndfremstillet papir, håndkoloreringen er intetsteds trængt gennem papiret, hvad den ofte gør på en original, og der er ingen ujævnheder eller tegn på ælde. Papiret har ingen vandmærker, som kunne tjene en identifikation. ${ }^{51}$ Konklusionen er, at Sankt Marie Kirkes eksemplar må stamme fra én af de mapper, Nationalmuseet udgav i 1977 og er derfor en kopi. Museum Sønderjyllands eksemplar er trykt hos Seneberg og er p.t. den eneste kendte original herfra med dette motiv.

\section{Perspektivering}

Hvordan kan man forstå de "konfessionelt betingede ændringer af et billede", som denne artikels undertitel nævner?

Efter reformationen var det ikke muligt at etablere et absolut tæt jerntæppe mellem den danske konges riger og lande og det ikke-protestantiske udland, selv om det blev forsøgt. Der var religiøse, politiske, militære og økonomiske grunde til, at et vist samkvem fandt sted. De herskende religiøse og politiske autoriteter måtte derfor acceptere, at der til deres områder kom et vist mål af ukorrekt materiale fra modparten. Dette materiale kunne både være afsendt med det formål at påvirke anderledes troende, men kunne også - som tilfældet var med bl.a. kistebillederne - tjene kommercielle formål, hvor der så var en katolsk "bivirkning". Det findes der et tydeligt eksempel på, nemlig et dansk bogomslag med billeder udført i træsnit og forsynet med moraliserende rim fra ca. $1800 .{ }^{52}$ Der er f.eks. et billede af en bonde, hvor teksten lyder: "Jeg ville ej min skolemester høre. Derfor må jeg nu ploven køre." Dristigt og konfessionelt græseoverskridende er et billede af en pave med pavekrone på hovedet og tredobbelt korsstav, hvor teksten er: "Jeg lærer jer alle." Det var jo skinbarlig "papisme" og ikke god latin i det protestantiske Danmark. Billedet kan kun være importeret og "fordansket" fra et overvejende katolsk land.

Hvis der eksisterede eller blev indført ideologisk ukorrekte materialer, som blev anset for at være tilstrækkeligt skadelige, forsøgte man herhjemme ofte at demontere det skadelige indhold ved at ændre de ukorrekte elementer. Det findes der en del eksempler på, bl.a. følgende: Bibelen er siden reformationstiden blevet oversat på mange måder, som indholdsmæssigt på væsentlige punkter afviger fra den katolske standardbibel, Vulgata. ${ }^{53}$ Men også historiske tekster fra middelalderen blev efter reformationen oversat, kommenteret og udgivet med en protestantisk fortolkning, i et forsøg på at legitimere protestantismen, især vedrørende kirkehistorien i almindelighed, og de kirkelige embeder $\mathrm{i}$ særdeleshed.

Slotspræst og kgl. historiograf Anders Sørensen Vedel (1542-1616) udgav således i 1579 Adam af Bremens (ca. 1040 - ca. 1081) værk om biskopperne af Hamborg-Bremens historie (Historia Ecclesiastica). Adam af Bremen fremstilles her som en slags tidlig protestant, bl.a. fordi han var kritisk over for nogle af de biskopper, han skildrede, og værket udkom i en politisk korrekt udgave med en del ændringer i forhold til originalen. Vedel udgav desuden Saxos Danmarkskrønike i en dansk oversættelse, hvis hovedformål var at skabe kontinuitet og legitimitet for den danske adel i forhold til middelalderen. I indledningen gav Vedel et kort rids over kristendommens historie i Danmark, naturligvis set med protestantiske briller og forsynet med de obligatoriske antikatolske bemærkninger. Kun i denne sammenhæng kan Saxo - iflg. Vedel - forstås rigtigt, idet Gud lod Luther genetablere den sande kirke, efter at djævelen havde overtaget den katolske. Vedel omarbejdede også den katolske pavehistorie fra 1479, udgivet af Platina i Venedig, In vitas summorum pontificum ad Sextum IV - "Om pavernes levned indtil Sixtus IV" - til et værk, der udkom i København 1571, og kom til at hedde Antichristus Romanus - "Den romerske antikrist". Vedel ændrede års- 
tal, som ellers var korrekte og tilføjede ukritisk mange ufordelagtige og udokumenterede legender om paverne. ${ }^{54}$

Fremgangsmåden med at ændre og omfortolke blev også benyttet på andre områder end de litterære, f.eks. i nogle tilfælde, hvis altertavlerne i de danske middelalderkirker var for "katolske" for reformatorerne. I Holstebro Kirke blev træskærerarbejdet på altertavlen, som fremstiller Jomfru Maria på dødslejet, omgivet af de tolv apostle, ændret til patriarken Jakob og hans tolv sønner fra Det gamle Testamente ved, at Maria fik fuldskæg, og lyset i hendes hånd blev ændret til et scepter På denne måde blev såkaldte "papistiske" motiver ændret til såkaldt "bibelske". I Bellinge Kirke blev de fire store latinske kirkefædre - Ambrosius, Augustin, Gregor og Hieronymus - som øjensynligt var for "katolske", ændret til de mere "evangeliske" fire evangelister - Hieronymus med løven blev let til Markus, nu med løve. ${ }^{55}$

\section{KILDER}

\section{Utrykte kilder:}

Aalborg Stadsarkiv(AaS): Johannes Evald Tang Kristensens arkiv (A2411). Løbenr. 10: Papirer vedr. Danske kistebilleder (breve fra V.E. Clausen, 1 . juni 1946 og 11. juni 1946). - Løbenr. 11: Fo1946 og 11. juni 1946).
tos af div. kistebilleder.

Trykte kilder:

13 skillings-tryk fra 1700- og 1800 årene. København genoptrykt 1977 .

Clausen, Helge (eget arkiv): Kistebillede: Den Hellige Jomfrue Maria. Luckander.

Kevelaer: Foto af nădebilledet af Jomfru Ma ria Consolatrix Afflictorum. 1640.

\section{LITTERATUR}

Asker, Randi: "Danske tresnitt og kistebrev i Norge", By og Bygd. Norsk Folkemuseums årbok 1947, s. 77-102.

Bäumer, Remigius og Leo Scheffczyk (udg.): Marienlexikon, St. Ottilien 19881994, 6 bd.

Christensen, Olav: Haderslev bys forste bogtrykker: Hinrich Luckander 1759-1792.
Landesmuseum Gottorf: To kistebilleder: Den Hellige Jomfrue Maria. Begge Luck243-II-239.

Museum Sønderiylland - Arkæologi Haderslev (MS): Kistebill - Arderologi Hader frue (MS): Kistebillede: Den Hellige Jomfrue Maria. Seneberg (museumsnum-
mer HAM 999x2769). mer HAM 999x2769).

Nationalmuseet: Kistebillede: Den Hel lige Jomfrue Maria. Luckander. Løbenr. 814/1948

Protokoll der Synodalversammlung zu Venlo im Jahre 1647 (i: Heckens, Jose og Richard Schulte Staade (udg.): ConKevelaer. Botschaft, Geschichte, GegenDen Hellige Jomfrue Maria. Luckander.

Med en fortegnelse over Luckander-tryk Haderslev 1959

Clausen, Helge: Sankt Marie Kirke i Haderslev 1908-2008. Jubilaumsskrift. København 2008. der", Sønderjysk Maanedsskrift 1964, s. 225-230. solatrix Afflictorum. Das Marienbild zu wart, Kevelaer 1992, s. XVII-XX

Sankt Marie Kirke, Haderslev: Kistebillede:

Clausen, V.E.: "De slesvigske kistebille-
Clausen, V.E. Det folkelige danske træsnit etbladstryk 1650-1870. København 1961. -2. rev. udg. Det folkelige danske træsnit etbladstryk 1565-1884. København 1985. Clausen, V.E.: Folkelig grafik i Skandinavien. København 1973 .

Dal, Erik (red.): Danske Provinstryk 1482 1830. En bibliografi udarbejdet af Grethe Larsen, bd. IV. Sønderjylland. København 1998, s. 1-6, 44-46

Frederiksen, Hans Jørgen: "Da Maria fik skæg. Nogle efterreformatoriske eksempler på ændringer af danske middelalderlige altertavler", Iconographisk Post nr. 2, 1983, s.17-29.

Friis-Jensen, Karsten: Vedels Saxo og den danske adel. Kobenhavn 1993. [Studie fra sprog- og oldtidsforskning $\mathrm{nr}$. 320 bd. 102, årg. 1992]

Heckens, Josef og Richard Schulte Staade (udg): Consolatrix Afflictorum. Das Marienbild zu Kevelaer. Botschaft, Geschichte, Gegenwart, Kevelaer 1992.

Henning Gustav: Historien om to kulenningsen, Gustav: Historien om to kulturskatte: Clausens og Fønss' samlinger af danske kistebilleder, Meddelelser til medlemmerne af Foreningen

Horstbøll, Henrik: Menigmands medie. Det orstbøll, Henrik: Menigmands medie. Det folkelige bogtryk i Danmark 1500-1840. En kulturhistorisk undersøgelse. København 1999. [Doktordisputats, Aarhu Universitet]

\section{NOTER}

1 For god service takkes Dansk Folkemindesamling, Nationalmuseet og Stadsarkivet i Aalborg. Niederrheinisches Museum i Kevelaer samt dets tidligere leder, Dr. Robert Plötz, Würzburg, takkes for oplysninger om billedet a Albrecht Schmidt. For kommentare vedrørende de to vers takkes Henrik Blicher, Thomas Bredsdorff, Pil Dahlerup, Flemming Lundgreen-Nielsen, Erik A. Nielsen og Sebastian Olden-Jørgensen. Endelig er jeg tak skyldig til tidl. fagleder Poul Steen Larsen, Danmarks Biblioteksskole.

2 Teksten findes i Sancti Gregorii Magn Epistolarium Lib. XI, Epist 13, Patrologia Latina, ed. J.P. Migne, LXXVII
Karker, Allan: Anders Sørensen Vedel og den danske krønike. København 1955. [Studier fra sprog- og oldtidsforskning, nr. 228, 1955]

Lundén, Tryggve (red.): Den heliga Birgitta. Himmelske uppenbarelser. Malmø 1967.

Nielsen, Erik A.: H.A. Brorson: Pietisme, meditation, erotik. København 2013

Nissen, Eduard A.: "Den katolske menighed i Fredericia 1674-1962". Særtryk af Vejle Amts Aarbog 1962.

Pötz, Robert: Gruß aus Kevelaer. Andachtsbilder aus vergangenen Zeiten. Kevelaer 2008(a).

Plötz, Robert: Maria "Trösterin der Betrübten". Zur Geschichte der Wallfahrt nach Kevelaer und ihres Bildes. Kevelaer 2008(b).

Schlee, Ernst: "Schleswiger Bilderbogen des 18. Jahrhunderts", Beiträge zur Schleswiger Stadtgeschichte 1963, s. 29-34.

Skovgaard-Petersen, Karen: "Skal den katolske fortid komme til orde? Anders Sørensen Vedels dilemma ved udgivelsen af Adam af Bremen i 1579", Fund og sen af Adam af Bremen i 1579", Fund og
forskning $i$ Det kongelige Biblioteks samforskning $i$ Det kong

Tang Kristensen, Johannes Evald: "Danske Kistebreve", Sprog og Kultur 1941, s.115-140. - "Et Supplement", Sprog og Kultur 1948, s. 65-95.

Vollmer, Hans (udg.): Allgemeines Lexikon der bildende Künstler. Bd. 30, Leipzig 1936.

Paris 1849, cols. 1128-1130. En engelsk oversættelse er i Caecilia Davis-Weyer: Early Medieval Art 300-1150: Sources and Documents. Toronto 1986, s. 48: "What
Scripture is to the educated, images are to the ignorant

www.kb.dk/da/nb/materialer/billeder/kistebilleder (set 31. juli 2017)

De tre eksempler omtales i Clausen 1985, s. 46; Dal 1998, s. 2 (Ha 6) og Clausen 1985, s. 48-49.

5 Clausen 1985, s. 12-14.

6 Clausen 1964, s. 227-228

7 Censur har i det mindste siden bogtrykkerkunstens ibrugtagning været anvendt af både de civile og religiøse myndigheder i stort set alle europæiske 
lande. Efter reformationen i Danmark kom der bestemmelser om censur i kirkeordinansen i 1539 og Christian V's Danske Lov i 1683. I hertugdømmet Slesvig skulle superintendenten fra 1637 censurere alle gejstlige bøger, hvilket i 1738 overgik til Overkonsistoriet, jf. Slesvigs delte Bispedømme, København 1949, s. 122. Censurbestemmelsern omhandler oftest trykte bøger, men har også omfattet pamfletter, flyveskrifte o.lign. Forhåndscensuren blev efterhånden afløst af et forfatter- og bogtrykkeransvar.

8 Om bestræbelserne på at udrydde uønskede katolske skikke mv. kan der henvises til de såkaldte visitats der feks. Peder Palladius' Visitatsbog, Kø-

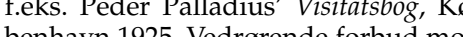
benhav 1925. Vedrorende forbud mod kat J. Nybo Rasmuss (red): Renvises til J. Nybo Rasmussen (red.). Religions frihed i 150 ar, Roskilde 1999, især artiklen "Katolikkers retsstilling fra refor-

9 mationen til grundloven", s. 10-37. s. 114.

10 Clausen 1985, s. 43-44, 46

11 Jf. Horstbøll 1999, s. 93

12 Clausen 1964, s. 230. Se også Dal 1998, s. 5, 45-46.

13 Asker 1945, s. 95, 96, 100. Det Kongelige Biblioteks eksemplar har accessionsnr. 1972-861/1. Clausen 1985, s. 62

14 Clausen 1973, s. 23

15 Clausen 1985, s. 62

16 Iklædning af Mariastatuer med dragter af stof kendes siden senmiddelalderen af stofn̊r et højdepunkt i baroktiden. Den specielle spanske kappe kan spoDen specielle spanske kappe kan spores tilbage til 1492, hvor den optræder
i Domkirken i Antwerpen. Den kendes bl.a. fra Mariavalfartsstederne Altötbl.a. fra Mariavalfartsstederne Altötting i Bayern, Luxembourg og Kevela-
er, se Bäumer og Scheffczyk bd. 1, 1988, er, se Bäumer og Scheffczyk bd. 1, 1988, s. $414 \mathrm{ff}$

17 Maria kan også have 12 stjerner om sit hoved som symbol på Israels 12 stammer / de 12 apostle, altså en universe enhed. I dette tilfælde er der dog kun fem, hvilket symboliserer Kristi fem sår, jf. Dahlby: Symboler i kirkens billedsprog, Kbh. 1985, s. 204, 205-206.

18 Nissen 1962, s. 15.

19 Lutherdommens opfattelse af Maria er et komplekst problem, som ikke kan behandles her. Generelt kan det dog siges, at reformatorerne afviste de katolske opfattelser af og praksis vedrørende bøn og andagt til Maria, Maria som forbederske, særlige valfartssteder for Maria og valfarter dertil. Man anerkendte Maria som jomfruen, der havd født Jesus, og derfor var hun værdig til kærlighed og respekt. Man forkastede generelt Mariadyrkelsen, fordi den ikke havde noget bibelsk fundament. Medvirkende hertil var de reformatoriske grundformler sola fide, sola scriptura, sola gratia (troen alene, Skriften alene, nåden alene). Se: Donald Attwater: A Dictionary of Mary, 1957, s. 230. Den A Dictionary of Mary, 1957, s. 230. Den Store Danske Encyklopædi (netudgaven, art. Maria). Hans Jørgen Frederiksen: Den katolske Kirke $-i$ kunstens spejl 2001, s. 62-63, 73. Lexikon für Theologie 1325. Lue, 3. udg., 2006, bd. 6, sp. 1324 1325. Luther selv gav dog et par gange udtryk for, at man godt kunne anråbe Maria, som også godt kunne være forbederske, dog uden at det forudsatte den bedendes fortjenester, jf. Bente Lybecker: Maria og Helligånden, 2003, s. 178-181.

20 Tang Kristensen 1941

21 AaS, A2411, løbenr. 10, brev fra V.E. Clausen, 1. juni 1946. V.E. Clausen var ansat ved Toldvæsenet og samlede pà kistebilleder, som han erhvervede sig en stor viden om. Se Danske historikere 1965, 1966, s. 31.

22 AaS, A2411, løbenr. 10, brev fra V.E. Clausen, 11. juni 1946

23 Ibid

24 Tang Kristensen 1948.

25 Tang Kristensen 194

1992.

Email til forf. fra Dr. Thomas Gädeke, Landesmuseen Schloss Gottorff, 20. november 2013.

27 Vollmer 1936, s. 131.

28 Schlee 1963, s. 31

Et eksempel er aftrykt i Plötz 2008a, s.

[7]. Dette billede angives at være fra 2.

tredjedel af 1700 -tallet.

30 Tang Kristensen 1948, s. 67.

31 Bäumer og Scheffczyk bd. 3, 1991, s. 685.

32 Læren om Marias optagelse i Himlen begrundes bibelsk af katolske teologer. Troen herpå er bevidnet i 200-tallet i den ældste kendte bøn til Maria
Sub tuum præsidium confugimus ("Til din beskyttelse tager vi vor tilflugt", jf. Bønnebog for Den katolske Kirke, 2013, s. 194) og blev formuleret som forpligtende troslære af pave Pius XII i 1950, jf.
Lexikon für Theologie und Kirche, 3. udg. Lexikon für Theologie und Kirche, 3. udg., bd. 1, Freiburg/Br. 2006, sp. 1216, 1218
- Den katolske opfattelse af Maria som Himlens Dronning baserer sig på flere gammel- og nytestamentlige bibelsteder, bl.a. englen Gabriels forudsigelse ved Bebudelsen af, at Jesus skal "være konge over Jakobs hus til evig tid" (Lukas 1,33a). Det teologiske ræsonnement er, at når Jesus er konge, må hans mor være dronning. Et andet vigtigt sted er synet af den apokalyptiske kvinde med stjernekransen i Johannes Åbenbaring 12,1. Maria som dronning omtales første gang hos Ephraim Syomtales frrste gang hos Ephraim Syreren (306-373), jf. Donald Attwater: A Diction fra $M a r y, 1957$, s. 234 . Alt $i$ alt má det fra en protestantisk synsvinke være mere acceptabelt, at Jesus fremstilles som konge med krone, end a Maria fremstilles som (Himmel)dronning. Dette er dog behæftet med en vis usikkerhed, idet de protestantiske ret-
ninger ikke har en fælles læremæssig ninger ikke har en

33 Bibelen, Jakobs brev 11, 'Johannes' Åbenbaring 2,10.

34 Nielsen 2013, s. 172-173

35 Kulturhistorisk leksikon for nordisk middelalder 1966, bd. 11, sp. 36

36 http://web.cathol.lu/article1452 (set 31. juli 2017).

37 Heckens og Staade 1992, s. XVII-XX Synoden gav Kirkens blå stempel til valfartsstedet og godkendte samtidig otte mirakuløse helbredelser, der havde fundet sted, jf. Plötz 2008b, s. 61.

38 Heckens og Staade 1992, s. 77-80. Opfattelsen af Maria som trøsterinde er $i$ tidens blev blevet udbygget og er fortsat en del af den katolske teologi (mariologien).

39 I 726 udstedte den byzantinske kejser Leo III et forbud mod brugen af religiøse billeder og statuer. Hermed indledtes billedstriden, som først blev afsluttet i 787, hvor det syvende økumeniske koncil i Nicæa godkendte brugen. Koncilet fordømte tilhængerne af gen. Koncilet fordømte tilhængerne af
at forbyde brugen af religiøse billeder som kættere. Billedstriden ebbede først ud i midten af 800-tallet.

0 Norman Davies: God's Playground. A History of Poland 2005, Vol. II, s. 200, 295.

1 Heckens og Staade 1992, s. 206 ff. Lexikon für Theologie und Kirche, 2. udg. 1965, sp. 944. Luther: "Das Bild der Gnade ist nichts anderes als Christus am Kreuz ...". Citatet er fra hans "Sermon von der Bereitung zum Sterben" Martin Luther Werke, Kritische Gesamtausgabe, Weimarer Ausgabe (WA 2) 1884, Bd. 2, s. 689

42 Denne antifon findes f.eks. i Breviarium Romanum. Pars Hiemalis, Rom 1952 s. [212]. Den kendes også fra dansk middelalder, se Steidl: Vor Frues Sange, Kbh. 1918, s. 143

43 Heckens og Staade 1992, s. 736-743. Et udvalg af grafiske afbildninger findes hos Plötz 2008(a) og 2008(b).

4 Plötz 2008(b), s. 8

45 Heckens og Staade 1992, s. 75

6 Heckens og Staade 1992, s. 214

47 Oratorianerordenen er en ordenskongregation for mænd, stiftet $1575 \mathrm{i}$ Rom af Filip Neri. Dens medlemmer arbejder i sognene og lægger særlig vægt på pastoralt arbejde og undervisning.

48 Se Peter Schmidt-Eppendorf: "Eine wechselvolle Geschichte verbindet Kevelaer und Nordstrand" i: Heckens og Staade 1992, s. 361-366.

49 www.gloria.tv/photo/FeVWrU9f2Rwr18Dmp1g6EoYaL (set 31. juli 2017).

50 Clausen 1985, s. 62. Nationalmuseets eksemplar har løbenr. 814/1948.

51 Emails til forf. fra Poul Steen Larsen 20. marts 2013.

52 Det Kongelige Bibliotek har en del eksemplarer af disse billeder, se f.eks. www.kb.dk/images/billed/2010/ okt/billeder/object294/da (set 31. juli 2017)

53 Her skal der kun gives nogle få eksempler, som stammer fra Luthers egen bibeloversættelse fra 1545: 1. Det klassiske eksempel er hans indsættelse af ordet "alene" i Romerbrevet 3,28, så der kom til at stå "... alene ved troen". -2. I Det nye Testamente anvender Luther kun ordet "kirke" én gang, nemig i Johannes' Åbenbaring 17,1, hvor han oversætter "den store skøge" med 
"den romerske kirke". I Vulgata forekommer "kirke" (ecclesia) ellers over 60 gange, men han anvender i stedet "menighed". - 3. Luther udelod syv gammeltestamentlige skrifter fra sin oversættelse, bl.a 2. Makkabæerbog, der omtaler offer og bøn for de afdøde (2 Makk 12,42-46), hvilket ikke kunne rummes i hans teologi. Luther har haft sine grunde til at foretage sådanne udeladelser og fortolkninger, som det ligger uden for denne artikels ramme at komme nærmere ind på. For øvrig er en del af Luthers ændringer ikk blevet medtaget i nyere protestantisk bibeloversættelser.

54 Skovgaard-Petersen 2004. Karker 1955. Friis-Jensen 1993, s. 28.

55 Frederiksen 1983.

\section{Zusammenfassung}

In der katholischen Sankt-Marienkirche und im Museum Sønderjylland in Hadersleben befinden sich zwei Varianten eines Truhenbriefes, die in der 2. Hälfte des 18. Jh. vor Ort gedruckt wurden. Das Motiv ist die Jungfrau Maria mit dem Jesuskind auf dem Arm. Der Artikel skizziert den Hintergrund der christlichen bildenden Kunst, besonders der Truhenbriefe und analysiert das Bild. In den 1940'er Jahren hatte ein dänischer Truhenbrief-Sammler nachgewiesen, dass es sich bei dem Bild um eine modifizierte Version des Andachtsbildes handelt, welches um 1640 in Kevelaer verehrt wurde und welches der Buchmaler und Formschneider Albrecht Schmidt aus Augsburg (nach 1744) für den Druck modifiziert hatte. Wahrscheinlich verlief der "Weg" des Bildes von Kevelaer nach Hadersleben über die Insel Nordstrand im Wattenmeer. Der Artikel vergleicht die beiden Bilder (Hadersleben und Kevelaer) und erläutert die verschiedenen Symbole unter Einbeziehung der lutherischen Auffassungen von Maria, der katholischen Mariologie und der kirchlichen Situation in Europa in der nachreformatorischen Zeit. Auf Grund u.a. einer Analyse des Papieres stellt sich heraus, dass das Bild der Sankt-Marienkirche eine Kopie aus dem Jahre 1977 ist. Das Bild im Museum Sønderjylland, dagegen, ist echt. Abschließend werden die konfessionell bedingten Änderungen des katholischen Bildes (damit es in einem lutherischen Zusammenhang annehmbar wurde), mit ähnlichen Beispielen (Altarbildern und Büchern) aus der nachreformatorischen Zeit in Dänemark verglichen.

\section{Lægedækningen i hertugdømmet Slesvig i slutningen af 1700 -tallet}

Af JohAnNes BRix

I en artikel i Flensburgsches Wochenblat fra 1789, advarer forfatteren på det kraftigste syge mod at henvende sig til kvaksalvere, men opfordrer i stedet til at konsultere en "rigtig" læge. På baggrund af denne artikel undersøges det for hertugdømmet Slesvigs vedkommende, hvordan mulighederne har været for at komme til en akademisk uddannet læge i slutningen af 1700-tallet og begyndelsen af 1800-tallet samt i hvilket omfang befolkningen benyttede sig af denne behandlergruppes færdigheder. Ved at sammenligne antallet af fysici (embedslæger) i Kongeriget og hertugdømmet Slesvig påvises det desuden, at der var færre indbyggere pr. fysicus i hertugdømmet.

\section{Indledning}

Sygdom og sundhed var i oplysningstiden og især i slutningen af 1700-tallet emner, der i stigende grad blev debatteret offentligt. I denne periode kan man i de trykte medier, der begyndte at blive publiceret, registrere en nytænkning på sundhedsområdet som skulle vise sig at påvirke samfundets syn på dette emne. ${ }^{1}$ Disse nye tanker kunne f.eks. dreje sig om, hvad der var god behandling for patienten og måske tillige hvad der kunne være nyttigt for samfundet.

Disse skriverier har efter alt at dømme haft indflydelse på de lovgivningsmæssige initiativer, der i sparsomt omfang begyndte at se dagens lys og har ydermere været med til at påvirke læsernes accept af disse. ${ }^{2}$

Et eksempel på en sådan artikel, der befattede sig med sundhedsproblemer, findes i "Flensburgsches Wochenblat für Jederman" i $1789 .{ }^{3} \mathrm{Ar}-$ tiklen havde overskriften "Von Pfushern, Quaksalbern und Salbadern behüt uns lieber Got". ${ }^{4}$ Denne overskrift mere end antyder forfatterens holdning til ikke autoriserede behandlere. I selve teksten kommer forfatteren med yderligere negative bemærkninger. Således skriver han, at det ikke ville være muligt for ham, til trods for, at han gjorde sig stor umage, at kende forskel på en gaderøver, skærslipper eller en kvaksalver. Hans aversion var så stor, at han end ikke ville lade sin hund be- 